\title{
Recovery of Antimony: A Laboratory Study on the Thermal Decomposition and Carbothermal Reduction of Sb(III), Bi(III), Zn(II) Oxides, and Antimony Compounds from Metal Oxide Varistors
}

\author{
Toni Karlsson $^{1}$ (D) $\cdot$ Christer Forsgren $^{2} \cdot$ Britt-Marie Steenari $^{1}$
}

Published online: 11 January 2018

(C) The Author(s) 2018. This article is an open access publication

\begin{abstract}
As antimony is typically present in industrial and commercial products only in small amounts, the concentration of antimony in waste types is low and a limited amount of antimony is currently recycled. One product relatively rich in antimony is the metal oxide varistor (MOV) used for overvoltage protection in electric circuits. To increase the antimony concentration, the MOV was pulverized $(<65 \mu \mathrm{m})$ and leached, resulting in an insoluble MOV residue containing $186 \pm 2 \mathrm{mg} / \mathrm{g}$ of antimony. This work investigates the thermal decomposition and carbothermal reduction of pure metal oxides $\left(\mathrm{Sb}_{2} \mathrm{O}_{3}, \mathrm{Bi}_{2} \mathrm{O}_{3}\right.$, and $\left.\mathrm{ZnO}\right)$ and $\mathrm{MOV}$ residue. Thermogravimetric (TG) analysis was used in order to propose a temperature range in which it is possible to separate antimony oxide from the MOV residue. TG results indicate that during thermal decomposition of pure metal oxides, sublimated antimony oxide can be recovered at $650{ }^{\circ} \mathrm{C}$, leaving $\mathrm{Bi}_{2} \mathrm{O}_{3}$ and $\mathrm{ZnO}$ unreacted. The addition of carbon caused mainly volatilization, with some reduction, of $\mathrm{Sb}_{2} \mathrm{O}_{3}$ and reduction of $\mathrm{Bi}_{2} \mathrm{O}_{3}$ to occur at nearly the same temperature, approximately $600{ }^{\circ} \mathrm{C}$. However, volatilization of $\mathrm{Bi}$ was not troublesome below $800{ }^{\circ} \mathrm{C}$ due to slow kinetics. Thermal decomposition of antimony from the MOV residue was not possible in the temperature range studied $\left(<1000{ }^{\circ} \mathrm{C}\right)$, while carbothermal reduction to the MOV residue revealed antimony volatilization occurred near $800{ }^{\circ} \mathrm{C}$.
\end{abstract}

Keywords Antimony $\cdot$ Varistor $\cdot$ Recycling $\cdot$ Bismuth $\cdot$ Carbothermal reduction

\section{Introduction}

Within the European Union (EU), the major use of antimony is in the form of antimony oxide $\left(\mathrm{Sb}_{2} \mathrm{O}_{3}\right)$ as a flame retardant in plastics and textiles [1]. Worldwide, metallic antimony is used in lead-acid batteries and in ammunition. Other uses are as a vulcanizing agent in rubber production, as a polymerization catalyst in the production of plastics and as a pigment in ceramic and glass [2].

The contributing editor for this article was Bernd Friedrich.

Toni Karlsson

tonig@chalmers.se

$1 \quad$ Industrial Materials Recycling, Department of Chemistry and Chemical Engineering, Chalmers University of Technology, Kemivägen 4, 41296 Gothenburg, Sweden

2 Stena Metall AB, Fiskhamnsgatan 8D, Box 4088, 40040 Gothenburg, Sweden
The EU is dependent entirely on imports of antimony [1], and in 2015 the United States (US) imported 23,600 metric tons of antimony for industrial consumption [3]. The antimony used in the US was imported mainly from the People's Republic of China (63\%), Bolivia (8\%), Belgium (7\%), and Thailand (6\%). The People's Republic of China is currently the leading producer of antimony with its government classifying antimony as a strategic material and controlling annual production quotas [3]. Currently, there are known to be 1.5 million tons of antimony reserves worldwide. At current mining rates, known antimony reserves will be depleted by 2027 [2].

From a recycling perspective, hardly any antimony is recycled. This is mostly because its applications are highly dispersive and collection is difficult [4]. Conventional recycling routes are typically not applicable to metals such as antimony [5] if no pretreatment step(s) to create concentrates are taken. Antimony is used extensively as a flame retardant, thus it is found in very low concentrations in plastics and textiles, making it impossible to design a 
recycling route from this waste stream [5] unless pretreatment steps are taken.

There are several waste streams from which antimony can be recovered; one success story is recycling antimony from lead-acid batteries. In the lead-acid battery, antimony is used in lead-antimony alloy plates in order to make this alloy harder. The concentration of antimony in lead-acid batteries has been declining due to advances in battery technology; however, the use of lead-acid batteries continues to increase. Nearly $85 \%$ of lead-acid batteries are recycled in the United States due to implementation of a policy restricting battery disposal in landfills and the availability of collection sites. Lead-acid batteries are the main source of secondary antimony. Antimony is recovered from the secondary lead smelter as an antimonial lead mixture and put back into production of new batteries [2]. In 2015, the US recycled 3850 metric tons of antimony [3].

Antimony recovery from municipal solid waste (MSW) incineration ash is another possible source of secondary antimony. MSW contains items having antimony thinly dispersed within them. Incineration can be thought of as a type of pretreatment step. Household wastes such as textiles contain $25.9 \mathrm{mg} / \mathrm{kg}$ antimony while plastics and rubber contain 12.9 and $8.4 \mathrm{mg} / \mathrm{kg}$, respectively [6]. Items such as curtains contain larger concentrations of antimony and things like wood contain much less antimony. It is estimated that the average antimony concentration in MSW is around $10-60 \mathrm{mg} / \mathrm{kg}[7,8]$. After incineration, the concentration of antimony in fly ash varies depending on the starting material and incineration conditions, but it has been shown to be less than $<2000 \mathrm{mg} \mathrm{Sb} / \mathrm{kg}$ dry ash [9-11].

In ammunition, lead is alloyed with antimony (2-5 wt\%) [12]; therefore, the accumulation of ammunition fired at shooting ranges could be a potential source of secondary antimony. In a study by Johnson et al. [12], the antimony concentration in shooting range soil samples was shown to be $35-17,500 \mathrm{mg} / \mathrm{kg}$.

In some cases, antimony is added to ceramics as a pigment and it can also be used to enhance specific characteristics. Antimony oxide is used in a type of ceramic known as the metal oxide varistor (MOV), which is a zinc oxide-based ceramic semiconducting device with a high degree of non-linear current-voltage characteristics. The main application of zinc oxide varistors is in circuits for overvoltage protection. An example of its use is in surge arrestors or lightening protectors on power lines [13]. Zinc oxide varistors are commonly referred to as MOVs due to the presence of zinc, bismuth, antimony, cobalt, manganese, and nickel oxides in addition to other metal oxides used in low amounts. It is not known how much antimony is available from varistors worldwide. However, used varistors could be a good source of recovered antimony since their $\mathrm{Sb}$ concentration is relatively high. In Sweden, it has been estimated that from 2009 to 2013 just over 520 metric tons of varistors were produced [14]. If secondary antimony oxide could be recovered, 23 metric tons of antimony would be available for reuse.

The MOV under investigation in this study is composed of sintered zinc oxide (88.2 wt\%), antimony trioxide (4.4 wt \%), bismuth trioxide (5.1 wt \%), cobalt trioxide $(<1 \mathrm{wt} \%)$, nickel oxide $(<1 \mathrm{wt} \%)$, and manganese carbonate $(<1 \mathrm{wt} \%)[15,16]$. Antimony oxide is used in the varistor to reduce the average size of the $\mathrm{ZnO}$ grain [17-19]. The microstructure of the MOV contains three phases, the most dominant phase being that of the zinc oxide grains. A bismuth-rich phase encompasses the zinc oxide grains and the antimony-rich phase is located within the bismuth oxide phase. XRD analysis has shown antimony compounds such as spinel $\left(\mathrm{Zn}_{7} \mathrm{Sb}_{2} \mathrm{O}_{12}, \mathrm{Zn}_{2.33}\right.$ $\left.\mathrm{Sb}_{0.67} \mathrm{O}_{4}\right)$ and pyrochlore $\left(\mathrm{Zn}_{2} \mathrm{Bi}_{3} \mathrm{Sb}_{3} \mathrm{O}_{14}\right)$ [16-18] to be present in the MOV.

It has previously been shown by Gutknecht et al. [15] that a pretreatment step such as acid leaching of the pulverized MOV material solubilizes the zinc oxide phase while leaving the antimony and bismuth-rich phases concentrated in the insoluble residue. Before leaching, the amount of antimony in the MOV was $35 \mathrm{mg}$ per gram $\mathrm{MOV}$; after leaching there were $186 \mathrm{mg}$ of antimony per gram residue, i.e., leaching as a pretreatment step increased the antimony concentration over 5 times.

Antimony is typically classified as a volatile heavy metal, and low-grade ores are commonly produced by pyrometallurgical methods [20]. Industrially, reduction of antimony oxide to metallic antimony is achieved by heating and the addition of carbon in a reverberatory furnace. Volatilization of antimony can be reduced by the addition of an alkaline flux but it cannot be eliminated [20] and volatilized antimony oxide is recovered in flues, condensing pipes, bag houses, precipitators, or a combination [21]. The volatile nature of antimony oxide can be utilized in designing a high-temperature method for separating gaseous antimony oxide from the matrix of the MOV leaching residue. Since the MOV residue is composed mainly of compounds containing zinc-antimony-oxygen, it was thought that the addition of carbon would help lower the $\mathrm{Sb}_{2} \mathrm{O}_{3}$ volatilization temperature by decomposition of the spinel/pyrochlore compounds.

\section{Materials and Methods}

This work used thermogravimetric analysis (TGA) to investigate the amount and rate of weight change of simple metal oxides and MOV residue as a function of temperature in inert and reducing conditions. Simple metal oxides 
were used as a reference to help predict the behavior of sintered metal oxide compounds $\left(\mathrm{Zn}_{7} \mathrm{Sb}_{2} \mathrm{O}_{12}, \mathrm{Zn}_{2.33}\right.$ $\mathrm{Sb}_{0.67} \mathrm{O}_{4}$, and $\mathrm{Zn}_{2} \mathrm{Bi}_{3} \mathrm{Sb}_{3} \mathrm{O}_{14}$ ) present in the MOV residue. Carbothermal reduction experiments were done to observe if the volatilization temperature can be lowered compared to thermal decomposition from heat treatment. From TG results, a suitable high-temperature separation process can be proposed for the recovery of volatilized antimony oxide from the MOV residue.

\section{MOV Pretreatment}

A pulverized (crushed to a particle size $<65 \mu \mathrm{m}$ ) $\mathrm{MOV}$ was leached at $\mathrm{pH} 4 \mathrm{using} \mathrm{H}_{2} \mathrm{SO}_{4}$. Sulfuric acid was used because the leachate, once separated from the insoluble residue, could be sold to a zinc electrowinning facility for the production of secondary metallic zinc. It was demonstrated that the leachate contained low concentrations of cobalt and nickel, which can be removed by cementation [16], as well as some manganese. In previous work, the concentration of zinc in the leachate was shown to be $1 \mathrm{~mol} / \mathrm{l}$ but can be increased to suit the needs of the electrowinning facility [16]. Other mineral acids as well as organic acids could also have been used for zinc leaching [15], but from those leachates, zinc or zinc oxide would have been recovered by precipitation or solvent extraction. The process for pretreatment of the MOV is described in detail in previous work by Gutknecht et al. [16].

In order to determine the composition of the insoluble MOV residue, a sample was dissolved in concentrated hydrochloric acid (37\%) for $24 \mathrm{~h}$ while being continuously stirred using a magnetic stir bar. The solution was bluegreen but transparent after dissolution. $\mathrm{HCl}$ was used due to the reported solubility of antimony compounds in concentrated hydrochloric media [22]. Elemental analysis using inductive coupled plasma with optical emission spectrometric detection (ICP-OES) (iCAP 6500, Thermo Fischer) yielded the results shown Table 1. The concentrations shown in Table 1 are given as milligrams of metal per gram of MOV residue. Metals account for approximately $85 \%$ of the MOV residue while it is assumed oxygen accounts for the remaining $15 \%$. It was reasonable

Table 1 Composition of the leaching residue given in $\mathrm{mg} / \mathrm{g}$

\begin{tabular}{ll}
\hline Metal & $\mathrm{mg} / \mathrm{g}$ \\
\hline $\mathrm{Bi}$ & $247 \pm 2$ \\
$\mathrm{Co}$ & $11.8 \pm 0.1$ \\
$\mathrm{Mn}$ & $14.7 \pm 0.1$ \\
$\mathrm{Ni}$ & $25.9 \pm 0.1$ \\
$\mathrm{Sb}$ & $186 \pm 2$ \\
$\mathrm{Zn}$ & $360 \pm 1$ \\
Total & $845 \pm 5$ \\
\hline
\end{tabular}

to assume oxygen makes up the remaining $15 \%$ due to $\mathrm{X}$-ray analysis and compound identification.

Starting materials were analyzed for purity and identification of crystalline compounds present in the samples using an X-ray diffractometer (Bruker 2D Phaser) equipped with a characteristic $\mathrm{Cu}$ radiation source and a scintillation detector. Compound identification was made by comparisons with standards in the Joint Committee of Powder Diffraction Standards database [23]. The appearance and composition of the dried residue was analyzed with a SEM: A FEI Quanta 200 environmental SEM equipped with Oxford Inca energy dispersive X-ray detector (EDX) system. Imaging was done with accelerating voltages between 10 and $20 \mathrm{kV}$ to obtain qualitative data about the elements present and to determine the occurrence and distribution of the components.

\section{Materials Used}

Pure samples of $\mathrm{Sb}_{2} \mathrm{O}_{3}$ (Sigma Aldrich, 99.9\%), $\mathrm{Bi}_{2} \mathrm{O}_{3}$ (Sigma Aldrich, 99.9\%), and $\mathrm{ZnO}$ (Sigma Aldrich, $\geq 99.9 \%$ ) were used to determine the temperature range needed to thermally decompose or reduce the pure oxides. Because X-ray powder diffraction patterns showed that the metal oxides supplied were pure, the oxides were used without any further purification.

The pure metal oxides were a less complex system than the MOV residue and they provided a good fundamental understanding of the behavior of the metal oxides prior to analysis of the more complex MOV residue system. Pure metal oxides were also used as quasi-method checks, since their thermal properties are well documented in literature. The MOV residue was prepared as previously described having the metal concentration as shown in Table 1. The microstructure of the MOV residue is shown in Fig. 1. There are two main phases in the MOV residue: the $\mathrm{Bi}_{2} \mathrm{O}_{3}$ phase and the antimony-rich phase containing compounds such as spinel $\left(\alpha-\mathrm{Zn}_{7} \mathrm{Sb}_{2} \mathrm{O}_{12}, \beta-\mathrm{Zn}_{2.33} \mathrm{Sb}_{0.67} \mathrm{O}_{4}\right)$ and pyrochlore $\left(\mathrm{Zn}_{2} \mathrm{Bi}_{3} \mathrm{Sb}_{3} \mathrm{O}_{14}\right)$.

In the MOV residue, it was seen that $\mathrm{Bi}_{2} \mathrm{O}_{3}$ encompassed the Sb-rich material as shown in Fig. 1. Cobalt, manganese, and nickel are also present in the MOV in much lower concentrations, most likely substituted into the spinel lattice. XRD analysis of the MOV residue supports this conclusion where peaks were seen for $\mathrm{Zn}-\mathrm{Co}-\mathrm{Sb}-\mathrm{O}$ and $\mathrm{Zn}-\mathrm{Ni}-\mathrm{Sb}-\mathrm{O}$ compounds. XRD also showed the presence of $\mathrm{Bi}_{2} \mathrm{O}_{3}, \mathrm{Zn}_{7} \mathrm{Sb}_{2} \mathrm{O}_{12}$, and $\mathrm{Zn}_{2} \mathrm{Bi}_{3} \mathrm{Sb}_{3} \mathrm{O}_{14}$.

\section{Thermogravimetric Experiments}

HSC Chemistry 9 software was used for thermodynamic calculations regarding the equilibrium composition and Ellingham diagram reactions over a temperature range 


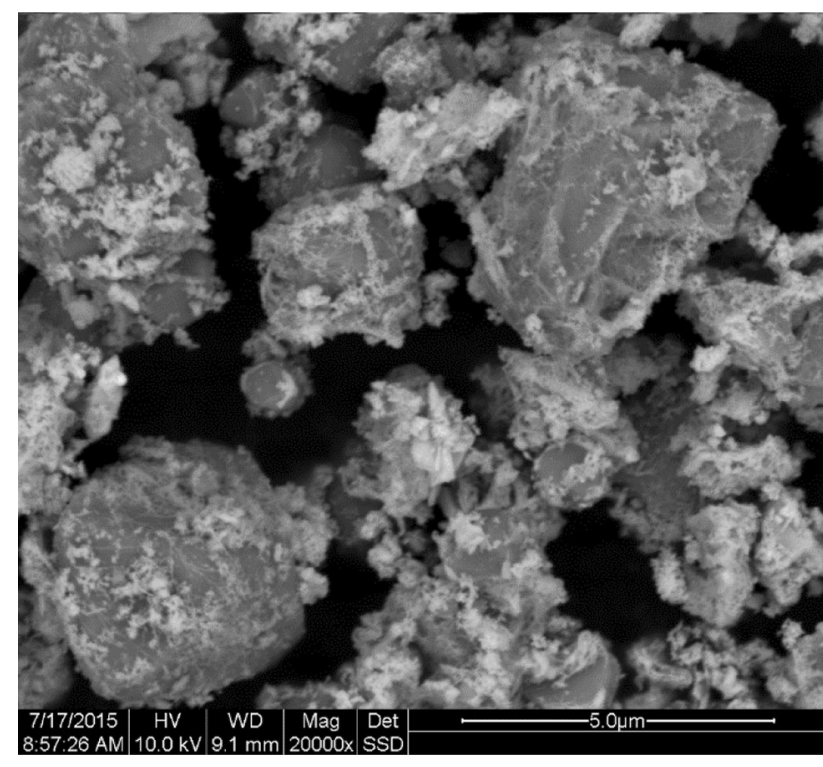

Fig. 1 SEM micrograph of MOV residue

from 100 to $1000{ }^{\circ} \mathrm{C}$ in a closed system. Thermogravimetric (TG) experiments were carried out on the $\mathrm{Sb}_{2} \mathrm{O}_{3}$, $\mathrm{Bi}_{2} \mathrm{O}_{3}, \mathrm{ZnO}$, and $\mathrm{MOV}$ residue using a TA Instruments TGA Q500 equipped with a single control/sample thermocouple positioned immediately adjacent to the sample. The TGA had a quartz-lined furnace with a nitrogen sample and balance purge gas. Use of the TG was limited to temperatures below $1000{ }^{\circ} \mathrm{C}$. Typical operating parameters for TG are given in Table 2. Thermolysis curves are displayed as \% mass loss $(\mathrm{m})$ versus temperature or when needed the derivative $(\Delta m / \Delta t)$ showing the rate of weight loss as a function of temperature. The TG was calibrated with five high-purity standards using their Curie temperature and peak inflection point as the calibration temperature.

Two general types of experiments were performed: (1) thermal decomposition where the metal oxides as well as MOV residue were heated in a nitrogen atmosphere and (2) carbothermal reduction where charcoal was added to the metal oxides and MOV residue. It has been proven to work

Table 2 Values of TG operating parameters

\begin{tabular}{ll}
\hline Variable & Value \\
\hline Reaction temperature $\left({ }^{\circ} \mathrm{C}\right)$ & $100-1000$ \\
Balance purge rate $(\mathrm{mL} / \mathrm{min})$ & 10 \\
Sample purge rate $(\mathrm{mL} / \mathrm{min})$ & 90 \\
Sample size $(\mathrm{mg})$ & 10 \\
Heating rate $\left({ }^{\circ} \mathrm{C} / \mathrm{min}\right)$ & 5 \\
Reaction gas & $\mathrm{N}_{2}$ \\
\hline
\end{tabular}

in zinc production [24] but the effect on the oxides of antimony and bismuth as well as the MOV residue is not well known.

For carbothermal reduction experiments, activated charcoal $\left(\mathrm{DARCO}^{\circledR},-100\right.$ mesh) was mixed with the metal oxides and the MOV residue at multiple $\mathrm{C} / \mathrm{O}$ molar ratios. Homogenization was done using a mortar and pestle. The $\mathrm{C} / \mathrm{O}$ ratio for the $\mathrm{MOV}$ residue was determined by assuming the MOV residue to be composed of $85 \%$ metals (determined by ICP-OES) with the remaining $15 \%$ being oxygen (Table 3 ).

\section{Results and Discussion}

\section{Thermodynamic Predictions}

Thermodynamic models based on the calculation of the variation of Gibbs free energy $\left(\Delta G^{\circ}\right)$ can point out which reactions are more likely to take place under the conditions in a thermal decomposition or carbothermal reduction. Thermodynamic calculations do not model exactly the real processes, since simplified assumptions have to be made (ideal thermodynamic conditions, homogeneous distribution of the elements, chemical equilibrium, etc.), which can be far from reality in some systems Nevertheless, thermodynamic models can be powerful tools for understanding chemical behavior during thermal and reducing conditions.

Thermodynamic analysis was done over a temperature range between 100 and $1000{ }^{\circ} \mathrm{C}$. The possible reactions occurring during thermal treatment of $\mathrm{Sb}_{2} \mathrm{O}_{3}, \mathrm{Bi}_{2} \mathrm{O}_{3}$, and $\mathrm{ZnO}$ are shown as a function of equilibrium composition in Fig. 2a. $\mathrm{Sb}_{2} \mathrm{O}_{3}(\mathrm{~s})$ starts to equilibrate with $\mathrm{Sb}_{2} \mathrm{O}_{3}(\mathrm{l})$ near $630{ }^{\circ} \mathrm{C}$, the predicted melting temperature of $\mathrm{Sb}_{2} \mathrm{O}_{3}$. It is also seen that $\mathrm{Sb}_{4} \mathrm{O}_{6}(\mathrm{~g})$ forms around the same temperature. $\mathrm{Bi}_{2} \mathrm{O}_{3}$ is stable through the entire temperature range.

Table 3 Molar ratio of $\mathrm{C} / \mathrm{O}$ used for carbothermal reduction

\begin{tabular}{ll}
\hline Compound & $\mathrm{C} / \mathrm{O}$ ratio used \\
\hline Antimony oxide, $\mathrm{Sb}_{2} \mathrm{O}_{3}$ & 2 \\
& 4 \\
Bismuth oxide, $\mathrm{Bi}_{2} \mathrm{O}_{3}$ & 2 \\
Zinc oxide, $\mathrm{ZnO}$ & 4 \\
MOV residue & 2 \\
& 4 \\
& 1.4 \\
& 2.2 \\
\hline
\end{tabular}



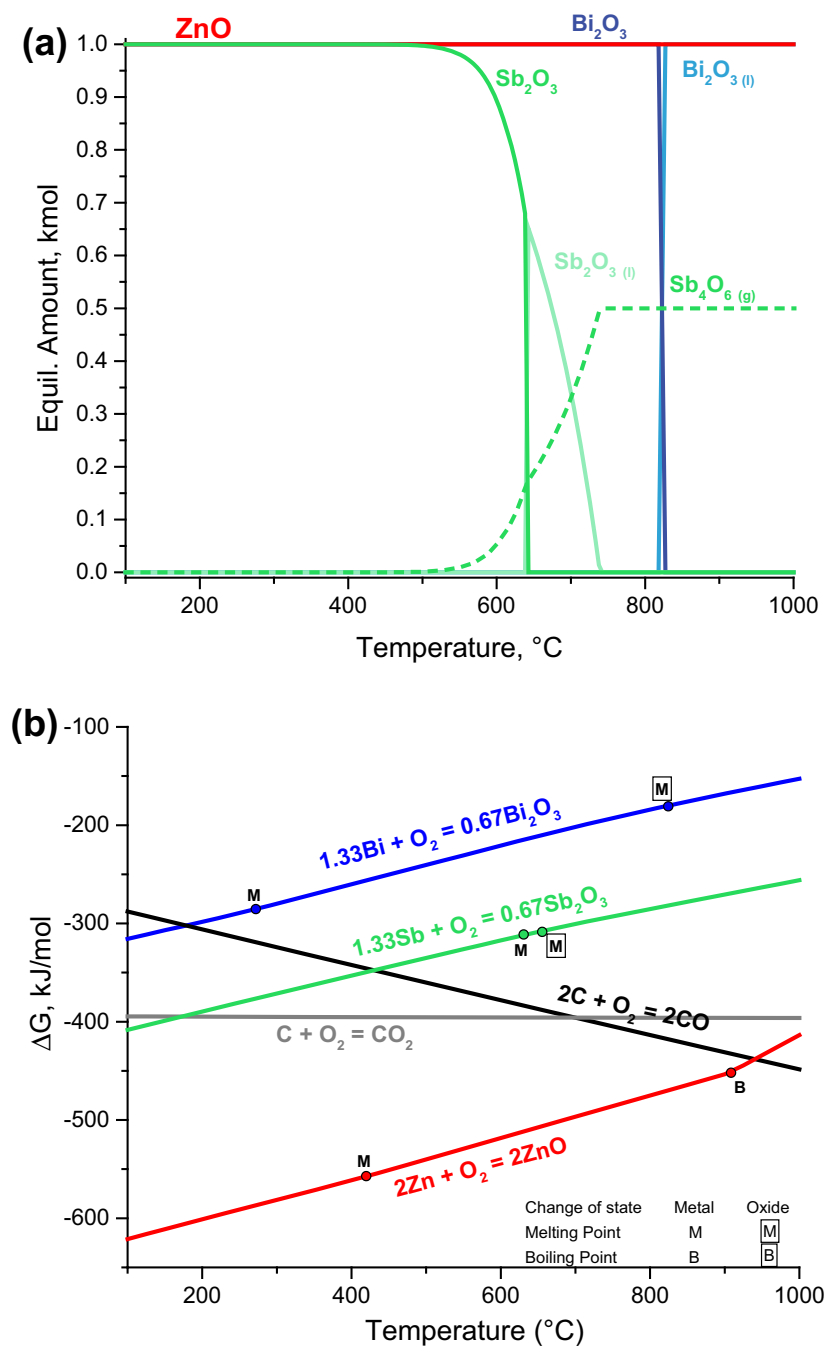

Fig. 2 a Equilibrium composition for heat-treated $\mathrm{Sb}_{2} \mathrm{O}_{3}, \mathrm{Bi}_{2} \mathrm{O}_{3}$, and $\mathrm{ZnO}$ in inert atmosphere. b Ellingham diagram for oxidation of metals. $P=1 \mathrm{~atm}$ (Color figure online)

Melting of $\mathrm{Bi}_{2} \mathrm{O}_{3}(\mathrm{~s})$ occurs at $825^{\circ} \mathrm{C}$. A phase transformation from $\alpha-\mathrm{Bi}_{2} \mathrm{O}_{3}$ (s) to $\gamma-\mathrm{Bi}_{2} \mathrm{O}_{3}(\mathrm{~s})$ takes place at $730{ }^{\circ} \mathrm{C}$ but is not shown in Fig. $2 \mathrm{a}$ since these data were not available in the HSC database. However, the transition was reported to occur by Irtyugo et al. [25]. $\mathrm{ZnO}$ is stable in the temperature range shown in Fig. 2 a.

An Ellingham diagram as shown in Fig. 2b was used to determine the variation of $\Delta G^{\circ}$ (compound stability) with temperature for the oxidation of a series of metals. The lower the position of a metal's line in the Ellingham diagram, the greater the stability of its oxide. For instance, $\mathrm{ZnO}$ is more stable than $\mathrm{Bi}_{2} \mathrm{O}_{3}$. In general, the stability of metal oxides decreases with temperature. A reduced metal, whose Gibbs free energy of formation is lower on the diagram at a given temperature, will reduce an oxide whose free energy of formation is higher on the diagram. For example, metallic zinc can reduce $\mathrm{Sb}_{2} \mathrm{O}_{3}$ to metallic antimony, the zinc itself being oxidized to $\mathrm{ZnO}$. Because the distance is greater between $\mathrm{Bi}_{2} \mathrm{O}_{3}$ and $\mathrm{ZnO}$ as compared to $\mathrm{Sb}_{2} \mathrm{O}_{3}$ and $\mathrm{ZnO}, \mathrm{Zn}$ will be more effective as a reducing agent for $\mathrm{Bi}_{2} \mathrm{O}_{3}$.

The $\Delta G^{\circ}$ of carbon dioxide $\left(\mathrm{CO}_{2}\right)$ is almost independent of temperature, while that of carbon monoxide (CO) has negative slope and intersects the $\mathrm{CO}_{2}$ line near $700{ }^{\circ} \mathrm{C}$. According to the Boudouard reaction (R1), carbon monoxide is the dominant oxide of carbon at higher temperatures (above $700{ }^{\circ} \mathrm{C}$ ), and the higher the temperature the more effective $\mathrm{CO}$ is as a reducing agent.

$2 \mathrm{CO} \leftrightarrow \mathrm{CO}_{2}+\mathrm{C}$

It can be expected from thermodynamic calculations that $\mathrm{Sb}_{2} \mathrm{O}_{3}$ will melt near $630{ }^{\circ} \mathrm{C}$ and the formation of $\mathrm{Sb}_{4}$ $\mathrm{O}_{6}(\mathrm{~g})$ upon further heating is also anticipated. During carbothermal reduction of $\mathrm{Sb}_{2} \mathrm{O}_{3}$, reduction of $\mathrm{Sb}_{2} \mathrm{O}_{3}$ is predicted to occur above $400{ }^{\circ} \mathrm{C}$, while reduction of $\mathrm{Bi}_{2} \mathrm{O}_{3}$ occurs near $200{ }^{\circ} \mathrm{C}$ and volatilization of $\mathrm{ZnO}$ at $900{ }^{\circ} \mathrm{C}$ with equilibrium between $\mathrm{CO}$ and $\mathrm{ZnO}$ occurring at $940{ }^{\circ} \mathrm{C}$.

\section{$\mathrm{Sb}_{2} \mathrm{O}_{3}$}

$\mathrm{Sb}_{2} \mathrm{O}_{3}$ is white, has a melting point of $656{ }^{\circ} \mathrm{C}$, and volatilizes thereafter [22]. There are two crystal structures of $\mathrm{Sb}_{2} \mathrm{O}_{3}$ : the cubic (senarmontite) consisting of $\mathrm{Sb}_{4} \mathrm{O}_{6}$ units [26] and orthorhombic (valentinite) having a layered structure [27]. Typically, commercial samples of $\mathrm{Sb}_{2} \mathrm{O}_{3}$ contain both cubic and orthorhombic forms of $\mathrm{Sb}_{2} \mathrm{O}_{3}$ [28]. The $\mathrm{Sb}_{2} \mathrm{O}_{3}$ used here was shown to be cubic by XRD. The structure of antimony(III) oxide in the vapor phase has been shown to be discrete $\mathrm{Sb}_{4} \mathrm{O}_{6}$ molecules of $\mathrm{Sb}_{4} \mathrm{O}_{6}$ which dissociate into $\mathrm{SbO}_{3}$ trigonal pyramidal units at high temperatures [29]. Heating causes the cubic phase to change to the denser (5.20-5.79 $\mathrm{g} / \mathrm{mL}$ ) orthorhombic form followed by a structural change to the polymeric form $\left[\mathrm{Sb}_{2} \mathrm{O}_{3}\right]_{n}[29]$. $\mathrm{Sb}_{4} \mathrm{O}_{6}($ cubic $) \stackrel{570^{\circ} \mathrm{C}}{\rightleftharpoons}\left[\mathrm{Sb}_{2} \mathrm{O}_{3}\right]_{n}($ orthorhombic $) \rightleftharpoons \mathrm{Sb}_{4} \mathrm{O}_{6}(\mathrm{l}) \rightleftharpoons \mathrm{Sb}_{4} \mathrm{O}_{6}(\mathrm{~g})$

The effect of mass loss as a function of heating rate on $\mathrm{Sb}_{2} \mathrm{O}_{3}$ is shown in Fig. 3a and the rate of mass loss is given in the derivative thermogravimetric (DTG) curve shown in Fig. 3b. It has been reported that the first thermal effect to occur upon heating senarmontite is the onset of sublimation occurring at approximately $500{ }^{\circ} \mathrm{C}[30,31]$. This is shown in Fig. 3a. From the DTG curve, the peak volatilization temperature was determined to be $644{ }^{\circ} \mathrm{C}$ at a heating rate of $20{ }^{\circ} \mathrm{C} / \mathrm{min}$ and decreased with slower heating rates. The temperature range in which $\mathrm{Sb}_{2} \mathrm{O}_{3}$ was sublimated was 500-650 ${ }^{\circ} \mathrm{C}$. Thermal decomposition curves indicate that $\mathrm{Sb}_{2} \mathrm{O}_{3}$ sublimated in one step from $\mathrm{Sb}_{2} \mathrm{O}_{3}(\mathrm{~s})$ to $\mathrm{Sb}_{4} \mathrm{O}_{6}(\mathrm{~g})$; this is seen in Fig. 3a where mass loss curves are smooth 

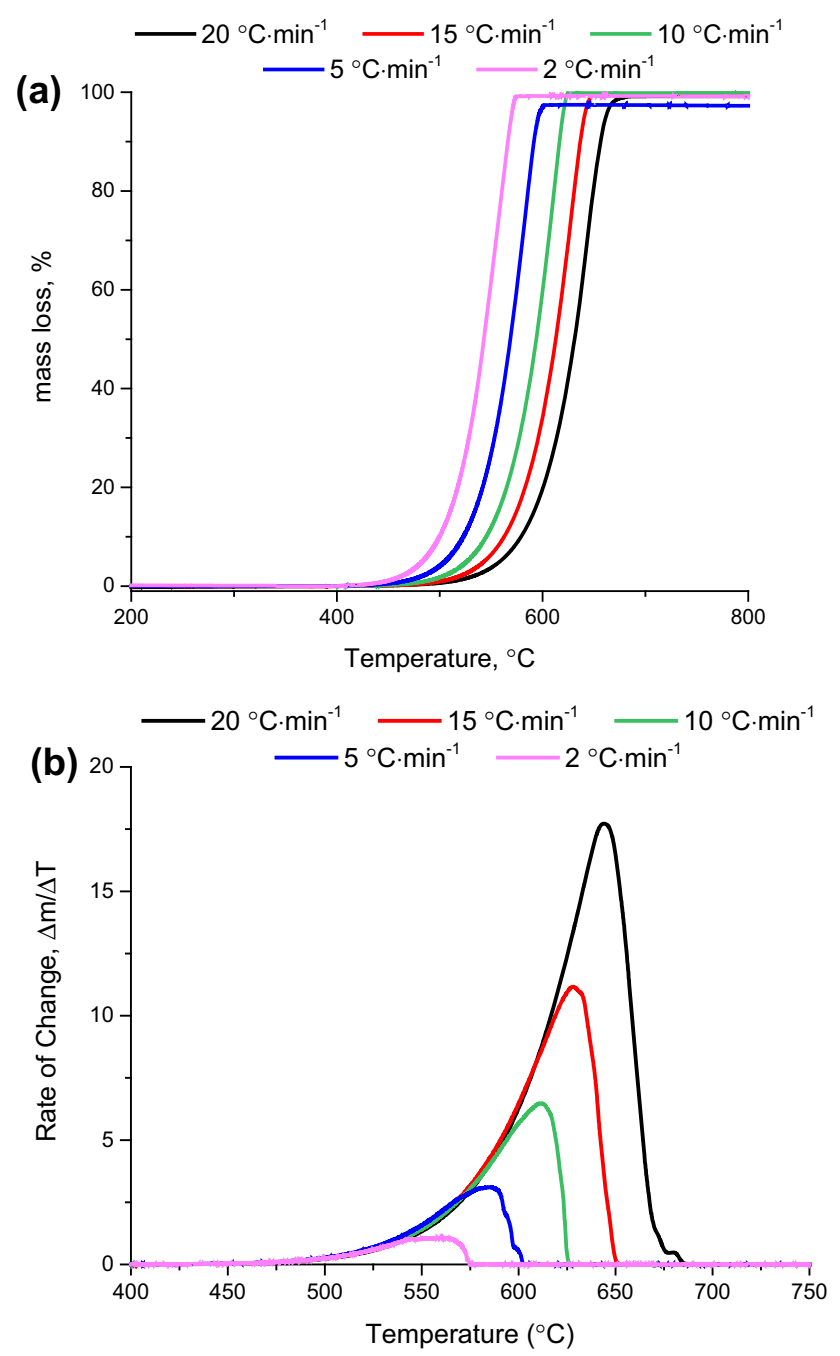

Fig. 3 a Effect of heating rate on direct thermal decomposition of $\mathrm{Sb}_{2} \mathrm{O}_{3}$ in nitrogen atmosphere. The heating rates used are 20, 15, 10, and $5{ }^{\circ} \mathrm{C} / \mathrm{min}$. b DTG curve (Color figure online)

and continuous. Similar results were reported by Orman et al. [32] for cubic $\mathrm{Sb}_{2} \mathrm{O}_{3}$ decomposition.

Generally, the oxides of more noble metals can be converted directly by thermal decomposition to metal from their oxides in the presence of a reducing agent, such as carbon. Antimony oxides can be reduced with charcoal in a reverberatory furnace at temperatures near $1200{ }^{\circ} \mathrm{C}$. The reaction proceeds according to reaction R2-R3 [20].

$\mathrm{Sb}_{2} \mathrm{O}_{3}+3 \mathrm{C} \rightarrow 2 \mathrm{Sb}+3 \mathrm{CO}$

$3 \mathrm{CO}_{2}+3 \mathrm{C} \rightarrow 6 \mathrm{CO}$

The thermograms for carbothermal reduction of antimony oxide are shown in Fig. 4. The addition of carbon to antimony oxide does nothing to lower the volatilization temperature. This is evident where each curve overlaps and has the same onset temperature for $\mathrm{Sb}_{2} \mathrm{O}_{3}$ volatilization. Complete volatilization of $\mathrm{Sb}_{2} \mathrm{O}_{3}$ (with no $\mathrm{Sb}_{2} \mathrm{O}_{3} / \mathrm{C}$

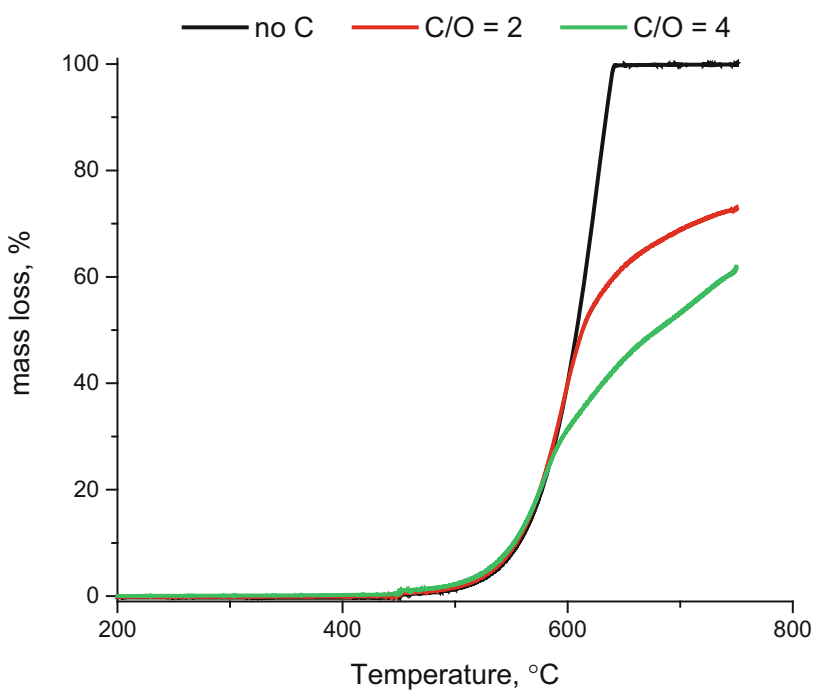

Fig. 4 Effect of molar ratio of $\mathrm{C} / \mathrm{O}$ on mass loss of $\mathrm{Sb}_{2} \mathrm{O}_{3}$ during heating to $750{ }^{\circ} \mathrm{C}$, isotherm for $10 \mathrm{~min}$, heating rate $10{ }^{\circ} \mathrm{C} / \mathrm{min}$ (Color figure online)

interaction) should result in 90 and $75 \%$ mass loss for $\mathrm{C} / \mathrm{O}$ of 2 and 4, respectively. TGA results show that 73 and $62 \%$ of sample mass was lost when the $\mathrm{C} / \mathrm{O}$ ratio was 2 and 4 , respectively. From Fig. 4 it can be see that the rate of mass loss changes in the presence of carbon around $600{ }^{\circ} \mathrm{C}$. The slower reaction kinetics could be due to the formation and then diffusion of $\mathrm{Sb}_{4} \mathrm{O}_{6}$ gas molecules through the sample. It could also be caused by carbothermal reduction of liquid or gaseous $\mathrm{Sb}_{2} \mathrm{O}_{3}$ which is predicted to occur near $430{ }^{\circ} \mathrm{C}$ from the Ellingham diagram shown in Fig. 2b. Antimony is less volatile than $\mathrm{Sb}_{2} \mathrm{O}_{3}$ and would therefore lower the rate of mass loss when compared to the pure $\mathrm{Sb}_{2} \mathrm{O}_{3}$ sample $[22,33]$. However, no further analysis was performed on the remaining residue and therefore the presence of antimony metal could not be determined.

\section{$\mathrm{Bi}_{2} \mathrm{O}_{3}$}

$\mathrm{Bi}_{2} \mathrm{O}_{3}$ has a melting point of $820{ }^{\circ} \mathrm{C}[29]$ and is volatile at higher temperatures. As shown in Fig. 5, the black curve shows no mass loss of $\mathrm{Bi}_{2} \mathrm{O}_{3}$ below $980{ }^{\circ} \mathrm{C}$ and therefore no thermal decomposition occurred. The addition of carbon to bismuth oxide results in carbothermal reduction of $\mathrm{Bi}_{2} \mathrm{O}_{3}$ into a metallic $\mathrm{Bi}$ product [34]. Carbothermal reduction reactions depicted in Fig. 5 show $\mathrm{Bi}_{2} \mathrm{O}_{3}$ was reduced to metallic $\mathrm{Bi}$ at $596{ }^{\circ} \mathrm{C}$, above which $\mathrm{Bi}$ started to volatilize. Mass balance calculations for carbothermal reduction of $\mathrm{Bi}_{2} \mathrm{O}_{3}$, to bismuth metal, predict a 15.6 and $13.8 \%$ mass loss for $\mathrm{C} / \mathrm{O}$ of 2 and 4, respectively. Theoretical data are in good correlation with experimental data. Increasing the $\mathrm{C} / \mathrm{O}$ molar ratio did not have any significant effect on the rate of carbothermal reduction. 


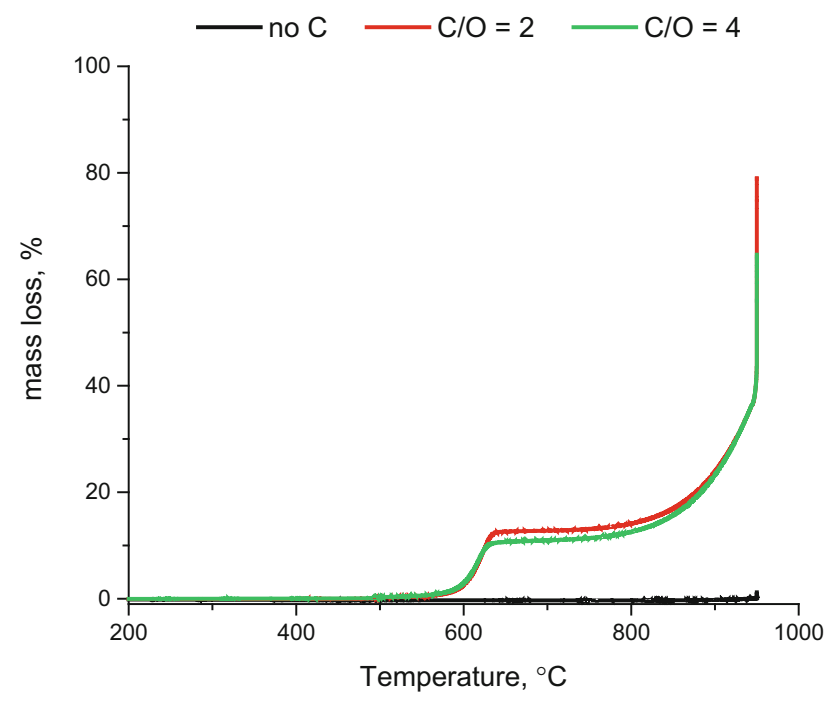

Fig. 5 Effect of molar ratio of $\mathrm{C} / \mathrm{O}$ on mass loss of $\mathrm{Bi}_{2} \mathrm{O}_{3}$ during heating to $980{ }^{\circ} \mathrm{C}$, heating rate $10{ }^{\circ} \mathrm{C} / \mathrm{min}, 30 \mathrm{~min}$ isotherm at $980{ }^{\circ} \mathrm{C}$ for $30 \mathrm{~min}$ (Color figure online)

Inspection of the sample after TG experiments indicated that carbon was added in excess and parts of it remained unreacted in the crucible. Mass balance calculations indicate that $50 \%$ of the carbon in the $\mathrm{C} / \mathrm{O}=2$ sample and $25 \%$ in the $\mathrm{C} / \mathrm{O}=4$ sample was used. Metallic pieces of bismuth metal were also seen in the crucible.

Complete carbothermal reduction and $\mathrm{Bi}$ volatilization would yield a mass loss of $93 \%$ and $82 \%$ for $\mathrm{C} / \mathrm{O}=2$ and 4 , respectively. In these experiments, the samples were heated to $980{ }^{\circ} \mathrm{C}$ and held isothermally for $30 \mathrm{~min}$. The TG curves indicate an $80 \%$ mass loss when the $\mathrm{C} / \mathrm{O}=2$ and $65 \%$ mass loss for $\mathrm{C} / \mathrm{O}=4$. The difference between theoretical and experimental results is explained by the kinetics of bismuth volatilization. It is possible that not all molten bismuth was volatilized before the end of the heating segment.

\section{$\mathrm{ZnO}$}

It is well known that in high-temperature zinc production carbon is added to zinc oxide causing carbothermal reduction, yielding zinc. Carbothermal reduction of zinc oxide occurs according to reactions R4-R5 [34]. For $\mathrm{ZnO}$ to be continuously reduced, the equilibria in R4 and R5 must be satisfied [35]. Reduction with carbon is governed by the chemical equilibria and reduction kinetics.

$\mathrm{ZnO}+\mathrm{CO} \rightarrow \mathrm{Zn}(\mathrm{g})+\mathrm{CO}_{2}$

$\mathrm{CO}_{2}+\mathrm{C} \rightarrow 2 \mathrm{CO}$

For zinc oxide, it is well documented that the melting point is $1975{ }^{\circ} \mathrm{C}$ and it does not thermally decompose below this temperature [22]. Carbothermal reduction of $\mathrm{ZnO}$ producing $\mathrm{Zn}(\mathrm{g})$ and $\mathrm{CO}_{2}(\mathrm{~g})$ has been shown to occur at $907{ }^{\circ} \mathrm{C}[36,37]$. TG curves of mass loss as a function of $\mathrm{C} / \mathrm{O}$ ratio are shown in Fig. 6. In the absence of carbon, zinc oxide showed no weight loss up to $950{ }^{\circ} \mathrm{C}$. The addition of carbon with a $\mathrm{C} / \mathrm{O}$ molar ratio of 2 and 4 resulted in carbothermal reduction of zinc starting near $800{ }^{\circ} \mathrm{C}$. The boiling point of $\mathrm{Zn}$ is $907^{\circ} \mathrm{C}$ under a pressure of 1 bar and evaporation starts when the partial pressure of vapor of the zinc is lower than the equilibrium vapor pressure $[22,38]$. As the temperature was increased, the rate of zinc reduction increased which has been seen in other reported in literature [37].

Volatilization of $\mathrm{Sb}_{2} \mathrm{O}_{3}$ occurred from 400 to $650{ }^{\circ} \mathrm{C}$ with the peak volatilization temperature of $644{ }^{\circ} \mathrm{C}$ at a heating rate of $20^{\circ} \mathrm{C} / \mathrm{min}$. The addition of carbon had no effect on the $\mathrm{Sb}_{2} \mathrm{O}_{3}$ volatilization temperature because of the low temperature at which sublimation occurred. However, the volatilization rate was affected due to carbothermal reduction of a portion of the $\mathrm{Sb}_{2} \mathrm{O}_{3}$ and subsequent volatilization of antimony. For $\mathrm{Bi}_{2} \mathrm{O}_{3}$, the addition of carbon resulted in a $10-15 \%$ mass loss near $600{ }^{\circ} \mathrm{C}$. The reaction thought to occur at this temperature is transition of $\mathrm{Bi}_{2} \mathrm{O}_{3}$ to molten $\mathrm{Bi}$. The melting temperature of $\mathrm{Bi}$ metal is $217{ }^{\circ} \mathrm{C}$ [29]. Another mass loss with onset near $875^{\circ} \mathrm{C}$ is due to volatilization of $\mathrm{Bi}$. It is known that bismuth metal is volatile at high temperatures. However, when in the presence of other metals, bismuth will not volatilize at high temperatures; rather it will alloy with the metals. Carbothermal reduction of $\mathrm{ZnO}$ to $\mathrm{Zn}(\mathrm{g})$ occurred just above $901{ }^{\circ} \mathrm{C}$ in these experiments. This is a very well-known reaction and the results obtained here correlate well with literature.

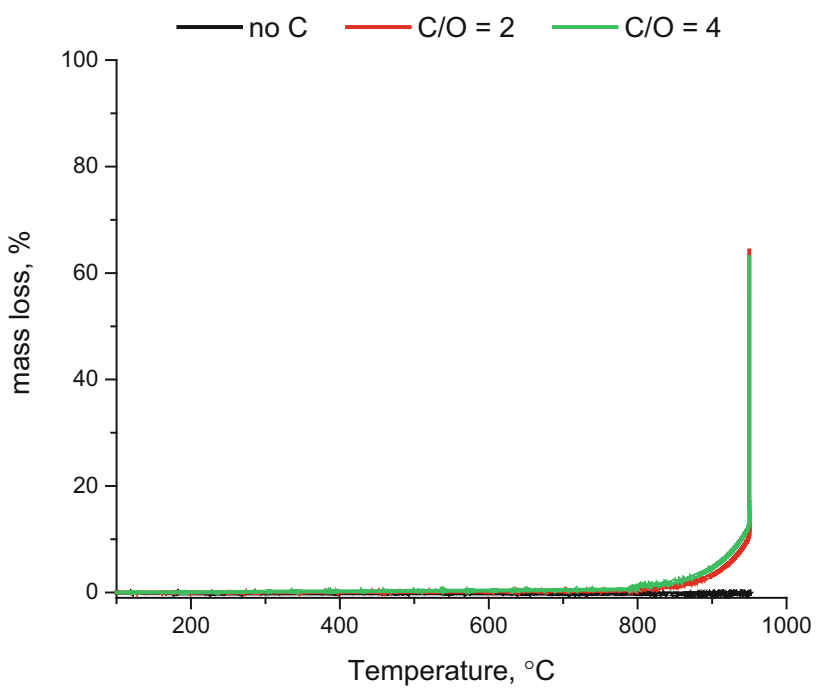

Fig. 6 Effect of molar ratio of $\mathrm{C} / \mathrm{O}$ on mass loss of $\mathrm{ZnO}$ during heating to $950{ }^{\circ} \mathrm{C}$, isotherm for $30 \mathrm{~min}$, and heating rate $10{ }^{\circ} \mathrm{C} / \mathrm{min}$ (Color figure online) 
Thermal treatment of the simple metal oxides suggests that sublimated antimony oxide could be separated from a mixture of $\mathrm{Sb}_{2} \mathrm{O}_{3}, \mathrm{Bi}_{2} \mathrm{O}_{3}$, and $\mathrm{ZnO}$ by heating to $650{ }^{\circ} \mathrm{C}$ and collected by distillation. The addition of carbon causes the volatilization of $\mathrm{Sb}_{2} \mathrm{O}_{3}$ and the reduction of $\mathrm{Bi}_{2} \mathrm{O}_{3}$ to occur at nearly the same temperature. If separation of bismuth and zinc was of interest, then after antimony volatilization, carbon could be added to lower the reduction temperature for their recovery.

\section{MOV and MOV Residue}

Prior to pretreatment, the MOV consisted of three main phases: firstly, the bulk zinc oxide phase, which accounted for nearly $90 \%$ of the MOV; secondly, the bismuth oxide phase, found in the region between the zinc oxide grains; and lastly the phase containing antimony compounds such as spinel $\left(\mathrm{Zn}_{7} \mathrm{Sb}_{2} \mathrm{O}_{12}\right)$ and pyrochlore $\left(\mathrm{Zn}_{2} \mathrm{Bi}_{3} \mathrm{Sb}_{3} \mathrm{O}_{14}\right)$. The antimony compounds are found within the bismuth oxide phase. Cobalt, manganese, and nickel are also present in the MOV most likely substituted into the spinel lattice. Work by Wong [39] determined that the octahedral crystal of the $\mathrm{Zn}_{7} \mathrm{Sb}_{2} \mathrm{O}_{12}$ spinel was doped with $\mathrm{Mn}$ and $\mathrm{Co}$ when $\mathrm{Mn}$ and Co were present during sintering. XRD analysis of the residue supports this conclusion where peaks were seen for $\mathrm{Zn}-\mathrm{Co}-\mathrm{Sb}-\mathrm{O}$ and $\mathrm{Zn}-\mathrm{Ni}-\mathrm{Sb}-\mathrm{O}$ compounds.

It was shown in previous research that leaching-pulverized MOVs with a $\mathrm{pH} 3$ sulfuric acid solution resulted in selective leaching of the zinc oxide phase, leaving the bismuth- and antimony-containing phases in the MOV residue [15]. XRD analysis of the residue showed the presence of $\mathrm{Bi}_{2} \mathrm{O}_{3}, \alpha-\mathrm{Zn}_{7} \mathrm{Sb}_{2} \mathrm{O}_{12}, \beta-\mathrm{Zn}_{2.33} \mathrm{Sb}_{0.67} \mathrm{O}_{4}$, and $\mathrm{Zn}_{2} \mathrm{Bi}_{3} \mathrm{Sb}_{3} \mathrm{O}_{14}$. There are two polymorphous forms of the $\mathrm{Zn}_{7} \mathrm{Sb}_{2} \mathrm{O}_{12}$ compound. The cubic $\alpha-\mathrm{Zn}_{7} \mathrm{Sb}_{2} \mathrm{O}_{12}$ having a crystal structure of the inverse spinel and orthorhombic $\beta$ $\mathrm{Zn}_{2.33} \mathrm{Sb}_{0.67} \mathrm{O}_{4}$, in which the crystal structure is not understood. $\mathrm{Mn}, \mathrm{Ni}$, and $\mathrm{Co}$ are substituted in the spinel lattice.

Since antimony is not found as $\mathrm{Sb}_{2} \mathrm{O}_{3}$ but within the spinel and pyrochlore compounds, the fate of antimony during thermal treatment of the MOV residue is not clear. The spinel compound has been reported to be stable up to $1350{ }^{\circ} \mathrm{C}$ [40]. Filipek et al. have suggested thermal decomposition of spinel occurs according to reaction R6.

$2 \alpha-\mathrm{Zn}_{7} \mathrm{Sb}_{2} \mathrm{O}_{12(\mathrm{~s})} \rightleftharpoons 14 \mathrm{ZnO}_{(\mathrm{s})}+\mathrm{Sb}_{4} \mathrm{O}_{6(\mathrm{~g})}+2 \mathrm{O}_{2(\mathrm{~g})}$

Thermal decomposition of the MOV residue in the absence of carbon resulted in less than $5 \%$ mass loss. The addition of carbon to the MOV residue had a large effect on the mass loss as seen in Fig. 7. For all samples containing carbon, there are four inflections indicating several stages
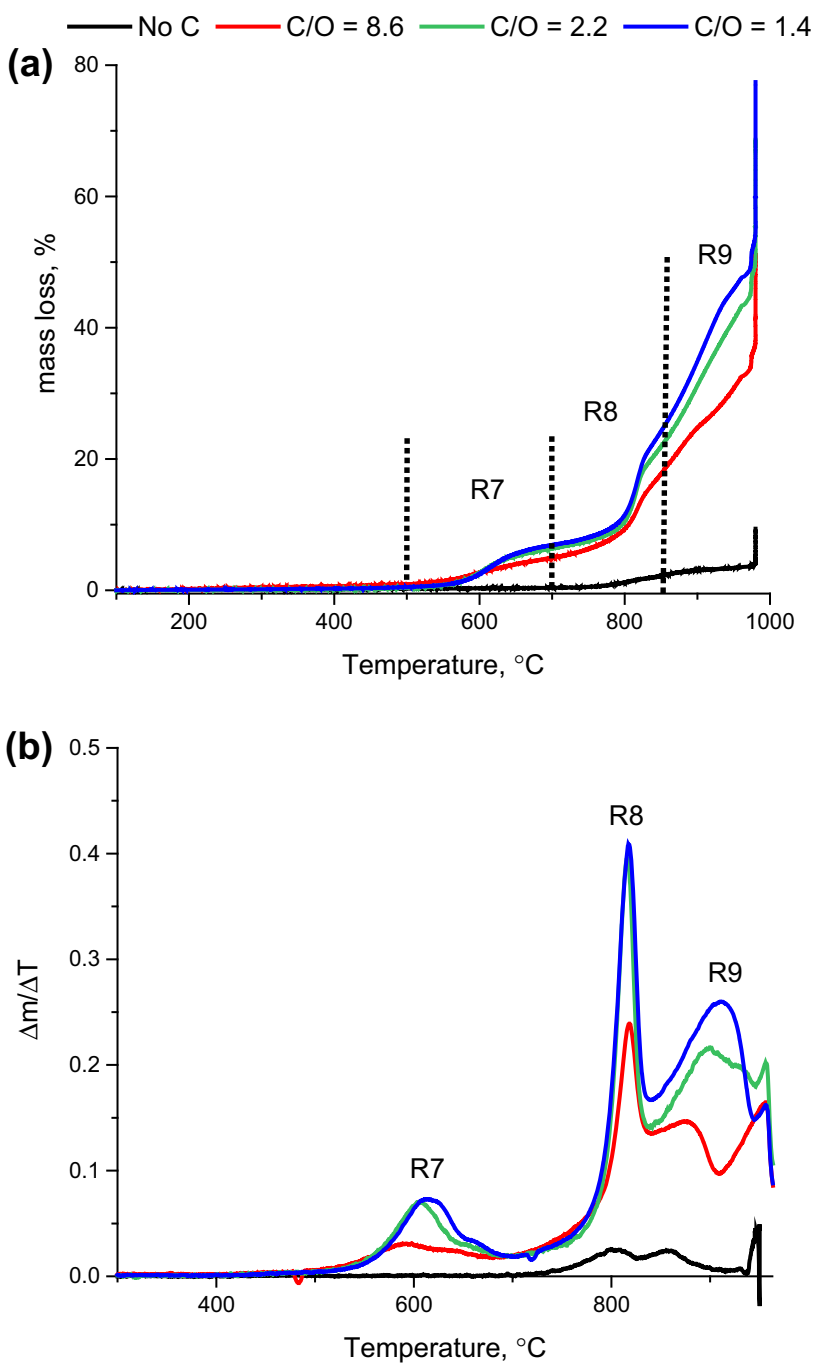

Fig. 7 a Effect of $\mathrm{C} / \mathrm{O}$ molar ratio on mass loss of MOV residue during heating to $980{ }^{\circ} \mathrm{C}$, heating rate $10^{\circ} \mathrm{C} / \mathrm{min}$. b Derivative curve for mass loss as a function of temperature (Color figure online)

of decomposition occurring in the MOV residue-carbon samples. Mass loss increased with temperature due to thermal decomposition, representing the mass of volatile matter removed from the sample. The decomposition regions are labeled in Fig. 7 and correspond to the decomposition reactions given in R7-R9. The decomposition mechanisms proposed are based on this research, literature data, and mass balance calculations.

$$
\begin{aligned}
& 500-700{ }^{\circ} \mathrm{C} \quad \mathrm{Bi}_{2} \mathrm{O}_{3(\mathrm{~s})}+3 \mathrm{C} \rightleftharpoons 2 \mathrm{Bi}_{(\mathrm{s})}+3 \mathrm{CO}_{(\mathrm{g})} \quad(\mathrm{R} 7) \\
& 700-850{ }^{\circ} \mathrm{C} \\
& 2 \mathrm{Zn}_{7} \mathrm{Sb}_{2} \mathrm{O}_{12(\mathrm{~s})}+4 \mathrm{C} \rightleftharpoons 14 \mathrm{ZnO}_{(\mathrm{s})}+\mathrm{Sb}_{4} \mathrm{O}_{6(\mathrm{~g})}+4 \mathrm{CO}_{(\mathrm{g})}
\end{aligned}
$$

$\sim 900^{\circ} \mathrm{C} \quad \mathrm{ZnO}_{(s)}+\mathrm{C} \rightleftharpoons \mathrm{Zn}_{(\mathrm{g})}+\mathrm{CO}_{(\mathrm{g})}$

The first reaction is the loss of oxygen forming liquid $\mathrm{Bi}$ (R7) occurring at $600{ }^{\circ} \mathrm{C}$. In the presence of carbon, R8 has 
Table 4 Theoretical mass loss (in wt $\%$ ) from mass balance calculations and experimental mass loss for reactions R7-R9

\begin{tabular}{|c|c|c|c|c|c|c|}
\hline \multirow[t]{2}{*}{ Reaction } & \multicolumn{3}{|l|}{ Theoretical } & \multicolumn{3}{|c|}{ Experimental } \\
\hline & $\mathrm{C} / \mathrm{O}=8.6$ & $\mathrm{C} / \mathrm{O}=2.2$ & $\mathrm{C} / \mathrm{O}=1.4$ & $\mathrm{C} / \mathrm{O}=8.6$ & $\mathrm{C} / \mathrm{O}=2.2$ & $\mathrm{C} / \mathrm{O}=1.4$ \\
\hline R7 & 2.5 & 4.0 & 4.3 & 4.6 & 6.3 & 6.8 \\
\hline R8 & 13.2 & 21.2 & 22.8 & 12.7 & 15.5 & 17.3 \\
\hline R9 & 24.9 & 39.9 & 42.9 & 34.2 & 46.9 & 54.2 \\
\hline Subtotal & 40.7 & 65.1 & 70.0 & 51.5 & 68.7 & 78.3 \\
\hline $\mathrm{Co}, \mathrm{Ni}, \mathrm{Mn}$ & 2.6 & 4.2 & 4.5 & & & \\
\hline $\mathrm{Bi}$ & 12.3 & 19.7 & 21.2 & & & \\
\hline $\mathrm{C}$ & 44.9 & 11.8 & 5.1 & & & \\
\hline Total & 109.1 & 103.0 & 102.3 & & & \\
\hline
\end{tabular}

been proposed as the decomposition mechanism for $\alpha$ $\mathrm{Zn}_{7} \mathrm{Sb}_{2} \mathrm{O}_{12}$. Complete decomposition of $\mathrm{Zn}_{7} \mathrm{Sb}_{2} \mathrm{O}_{12}$ would result in a theoretical mass loss of approximately $65.7 \%$ when the $\mathrm{C} / \mathrm{O}=1.4$. The experimental mass loss between 700 and $980{ }^{\circ} \mathrm{C}$ was $71.5 \%$, indicating that the decomposition of spinel occurs in this range. In addition it is possible that a portion of the $\mathrm{Bi}$ was also volatilized in this range explaining why the experimental mass loss is higher than theoretical mass loss.

Since it is known that $\mathrm{ZnO}$ decomposed according to $\mathrm{R} 9$ near $900{ }^{\circ} \mathrm{C}$, the reaction near $800{ }^{\circ} \mathrm{C}$ is assumed to be volatilization of $\mathrm{Sb}_{4} \mathrm{O}_{6}$. The theoretical weight loss is $22.8 \%$, while the experimental weight loss for $\mathrm{Sb}_{4} \mathrm{O}_{6}$ and $\mathrm{CO}$ was $17.3 \%$. The difference in values is expected due to multiple reactions occurring near $900{ }^{\circ} \mathrm{C}$. This is depicted in Fig. 7b, where the derivative curve does not return to baseline before the $\mathrm{ZnO}$ reduction reaction (R9) begins.

The calculated and experimentally determined weight losses for reactions R7-R9 are given in Table 4. Theoretical weight loss calculations were made using the following assumptions and the composition of the MOV residue given in Table 1:

1. All $\mathrm{Bi}$ in the sample is in the form of $\mathrm{Bi}_{2} \mathrm{O}_{3}$.

2. All $\mathrm{Sb}$ in the sample is in the form $\mathrm{Zn}_{7} \mathrm{Sb}_{2} \mathrm{O}_{12}$. This also accounts for $97 \%$ of the $\mathrm{Zn}$ in the sample.

3. Liquid $\mathrm{Bi}, \mathrm{Co}, \mathrm{Ni}, \mathrm{Mn}$ remain as a solid in the residue.

4. The $\mathrm{C}$ used is calculated from reactions $\mathrm{R} 7-\mathrm{R} 9$.

There are small deviations when comparing theoretical and experimental data. From the derivative curves shown in Fig. 7b, it is seen that decomposition R8 is not complete before decomposition R9 begins. Multiple reactions occur simultaneously; therefore the experimental mass loss from an explicit decomposition reaction should only be viewed as an estimate. Simultaneous reactions will cause deviation between theoretical and experimental data. Also, the volatilization of $\mathrm{Bi}$ could not be accounted for in the theoretical calculations and therefore the mass loss will always be slightly lower than the experimentally obtained data.
Metals such as cobalt, nickel, and manganese make up less than $5 \%$ of the MOV residue and are not accounted for in the mass balance calculations. Since they are substituted into the spinel lattice they are believed to remain after decomposition and volatilization of zinc and antimony. As shown in Table 4, Subtotal refers to total mass loss from reaction $\mathrm{R} 7-\mathrm{R} 9$ while Total accounts for the other metals (Co, Ni, Mn), liquid bismuth, and unreacted carbon. The $\mathrm{Bi}$, unreacted carbon, and other metal remains are assumed to remain in the solid phase and do not contribute to mass loss.

It has been reported once that molten bismuth will volatilize at high temperatures. This is seen in Fig. 5 when reducing pure $\mathrm{Bi}_{2} \mathrm{O}_{3}$. The weight loss curve above $700{ }^{\circ} \mathrm{C}$ is smooth with no sharp inflection points, indicating the slow kinetics of bismuth volatilization. In the presence of other metals, bismuth tends to be less volatile. It can be concluded that some of the bismuth remained in the sample and some was volatilized. This would also explain the deviation between theoretical and experimental mass loss.

\section{Conclusions}

The MOV under investigation in this study was composed of sintered metal oxides of zinc, antimony (3.2 mol\%), bismuth (2.3 mol\%), cobalt $(<1 \mathrm{~mol} \%)$, nickel $(<1 \mathrm{~mol} \%)$, and manganese $(<1 \mathrm{~mol} \%)$ [15, 16]. The microstructure of the MOV contains three phases: the most dominant phase is that of the zinc oxide grains; the bismuth-rich phase encompasses the zinc oxide grains; and the antimony-rich phase is located within the bismuth oxide phase.

When recycling low concentration metals from waste, pretreatment is often needed. Pulverized $(<65 \mu \mathrm{m}) \mathrm{MOV}$ was leached at $\mathrm{pH} 4$ using $\mathrm{H}_{2} \mathrm{SO}_{4}$ yielding a pure zinc sulfate solution and an antimony-rich residue. XRD analysis showed antimony compounds such as $\mathrm{Zn}_{7} \mathrm{Sb}_{2} \mathrm{O}_{12}$, $\mathrm{Zn}_{2.33} \mathrm{Sb}_{0.67} \mathrm{O}_{4}$, and $\mathrm{Zn}_{2} \mathrm{Bi}_{3} \mathrm{Sb}_{3} \mathrm{O}_{14}$ as well as $\mathrm{Bi}_{2} \mathrm{O}_{3}$ to be present in the insoluble $\mathrm{MOV}$ residue. 
In this work, thermogravimetry was used to investigate the weight loss and rate of weight change of simple metal oxides $\left(\mathrm{Sb}_{2} \mathrm{O}_{3}, \mathrm{Bi}_{2} \mathrm{O}_{3}, \mathrm{ZnO}\right)$ as well as those of the MOV leaching residue as a function of temperature in inert and reducing conditions. Simple metal oxides were used as a reference to help predict the behavior of the sintered metal oxide compounds $\left(\mathrm{Zn}_{7} \mathrm{Sb}_{2} \mathrm{O}_{12}, \mathrm{Zn}_{2.33} \mathrm{Sb}_{0.67} \mathrm{O}_{4}\right.$, and $\mathrm{Zn}_{2}$ $\mathrm{Bi}_{3} \mathrm{Sb}_{3} \mathrm{O}_{14}$ ) present in the MOV residue.

The thermal treatment of the simple metal oxides suggested that sublimated antimony oxide could be separated from a mixture of $\mathrm{Sb}_{2} \mathrm{O}_{3}, \mathrm{Bi}_{2} \mathrm{O}_{3}$, and $\mathrm{ZnO}$ by heating to $650{ }^{\circ} \mathrm{C}$ and collected by distillation. The addition of carbon causes volatilization and reduction of $\mathrm{Sb}_{2} \mathrm{O}_{3}$ followed by subsequent $\mathrm{Sb}$ volatilization at a slower rate than for $\mathrm{Sb}_{2} \mathrm{O}_{3}$. Carbothermal reduction of $\mathrm{Bi}_{2} \mathrm{O}_{3}$ and subsequent volatilization of $\mathrm{Bi}(\mathrm{l})$ occurred at nearly the same temperature. For the separation of bismuth and zinc, once antimony was volatilized, carbon could be added to lower the reduction temperature for their recovery.

It was not known whether the spinel $\mathrm{Zn}_{7} \mathrm{Sb}_{2} \mathrm{O}_{12}$ is found in the cubic, orthorhombic, or a mixture of both forms in the MOV residue. Also, some antimony may be found in the pyrochlore $\mathrm{Zn}_{2} \mathrm{Sb}_{3} \mathrm{Bi}_{3} \mathrm{O}_{14}$ phase. For this work, all mass balance calculations were made assuming antimony was in the $\mathrm{Zn}_{7} \mathrm{Sb}_{2} \mathrm{O}_{12}$ compound. This could give rise to small deviations in mass balance calculations. The major part of theoretical deviations are most likely due to $\mathrm{Bi}$ vaporization.

Others have suggested thermal decomposition of spinel occurs near $1350{ }^{\circ} \mathrm{C}$ yielding $\mathrm{ZnO}$ and $\mathrm{Sb}_{4} \mathrm{O}_{6}$. Therefore, spinel decomposition was not expected to occur below $1350{ }^{\circ} \mathrm{C}$ without the addition of carbon. It was seen that decomposition of the MOV residue in the absence of carbon resulted in less than 5\% mass loss. The addition of carbon to the MOV residue had a large effect on the mass loss. The first reaction, occurring around $600{ }^{\circ} \mathrm{C}$, was the reduction of $\mathrm{Bi}_{2} \mathrm{O}_{3}$ from the $\mathrm{MOV}$, while near $800{ }^{\circ} \mathrm{C}$ volatilization of $\mathrm{Sb}_{4} \mathrm{O}_{6}$ occurred. The theoretical weight loss was $22.8 \%$, while the experimental weight loss for $\mathrm{Sb}_{4} \mathrm{O}_{6}$ and $\mathrm{CO}_{2}$ was $17.3 \%$. At temperatures above $900{ }^{\circ} \mathrm{C}$, zinc was volatilized and reduced.

Thermal treatment and carbothermal reduction of $\mathrm{Bi}_{2} \mathrm{O}_{3}$ showed that once reduced, Bi metal was slowly volatilized. This is also believed to occur during carbothermal reduction of the MOV residue. Therefore, antimony can be collected from the vapor phase at $800{ }^{\circ} \mathrm{C}$ with small amount of bismuth present. Further separation of antimony and bismuth was not investigated here.

Acknowledgements The authors of this work would like to thank their colleagues Volkmar Frick and Mikael Karlsson for their contributions to this work. Funding was provided by Chalmers Area of Advance Production, which is gratefully acknowledged.

\section{Compliance with Ethical Standards}

Conflict of interest The authors declare that they have no conflict of interest.

Open Access This article is distributed under the terms of the Creative Commons Attribution 4.0 International License (http://creative commons.org/licenses/by/4.0/), which permits unrestricted use, distribution, and reproduction in any medium, provided you give appropriate credit to the original author(s) and the source, provide a link to the Creative Commons license, and indicate if changes were made.

\section{References}

1. CRM-EU (Critical Raw Materials for the EU) (2010) Report of the Ad hoc Working Group on defining critical raw materials. http://ec.europa.eu/enterprise/policies/rawmaterials/documents/ index en.htm

2. Guberman DE (2017) Mineral information antimony. In: USGS (ed.) US Geological Survey, Mineral Commodity Summaries, Washington, DC

3. Guberman DE (2014) US Geological Survey, Mineral Commodity Summaries, Washington, DC, p 196

4. Graedel TE, Reck BK (2014) Chapter 3-recycling in context. In: Worrell E, Reuter MA (eds) Handbook of recycling. Elsevier, Boston, pp 17-26

5. Rombach E, Friedrich B (2014) Chapter 10-recycling of rare metals. In: Worrell E, Reuter MA (eds) Handbook of recycling. Elsevier, Boston, pp 125-150

6. Nakamura K, Kinoshita S, Takatsuki H (1996) The origin and behavior of lead, cadmium and antimony in MSW incinerator. Waste Manag 16(5):509-517

7. Paoletti F, Sirini P, Seifert H, Vehlow J (2001) Fate of antimony in municipal solid waste incineration. Chemosphere 42(5-7):533-543

8. van Velzen D, Langenkamp H, Herb G (1998) Antimony, its sources, applications and flow paths into urban and industrial waste: a review. Waste Manag Res 16(1):32-40

9. Takaoka M, Yamamoto T, Tanaka T, Takeda N, Oshita K, Uruga $\mathrm{T}$ (2005) Direct speciation of lead, zinc and antimony in fly ash from waste treatment facilities by XAFS spectroscopy. Phys Scr 2005(T115):943

10. Wang L, Chen Q, Jamro IA, Li R, Li Y, Li S, Luan J (2016) Geochemical modeling and assessment of leaching from carbonated municipal solid waste incinerator (MSWI) fly ash. Environ Sci Pollut Res 23(12):12107-12119

11. Johansson I, Sahlin E, Bahr BV, Björkmalm J, Olsson JT (2013) Kritiska metaller i svenska avfallsaskor. In: The content of critical elements in residues from Swedish waste-to-energy plants. SP Sveriges Tekniska Forskningsinstitut, Waste Refinery, Borås

12. Johnson CA, Moench H, Wersin P, Kugler P, Wenger C (2005) Solubility of antimony and other elements in samples taken from shooting ranges. J Environ Qual 34(1):248-254

13. Levinson LM, Philipp HR (1986) Zinc oxide varistors-a review. Ceramic Bulletin 65(4):639-646

14. Hultgren H (2014) Varistor material information. Personal communication

15. Gutknecht T, Gustafsson AMK, Forsgren C, Ekberg C, Steenari B-M (2017) Investigations into recycling zinc from used metal oxide varistors via ph selective leaching: characterization, leaching, and residue analysis. Sci World J 2015:11 
16. Gutknecht T, Colombus Y, Steenari B-M (2017) Recycling zinc from metal oxide varistors through leaching and cementation of cobalt and nickel. J Sustain Metall 3(2):239-250

17. Bernik S, Maček S, Bui A (2004) The characteristics of $\mathrm{ZnO}-$ $\mathrm{Bi}_{2} \mathrm{O}_{3}$-based varistor ceramics doped with $\mathrm{Y}_{2} \mathrm{O}_{3}$ and varying amounts of $\mathrm{Sb}_{2} \mathrm{O}_{3}$. J Eur Ceram Soc 24(6):1195-1198

18. Arefin ML, Raether F, Dolejš D, Klimera A (2009) Phase formation during liquid phase sintering of $\mathrm{ZnO}$ ceramics. Ceram Int 35(8):3313-3320

19. Kim JC, Goo E (1989) Morphology and formation mechanism of the pyrochlore phase in $\mathrm{ZnO}$ varistor materials. J Mater Sci 24(1):76-82

20. Anderson CG (2012) The metallurgy of antimony. Chem Erde Geochem 72(Supplement 4):3-8

21. Carlin JF (2000) Antimony recycling in the United States in 2000. In: Flow studies for recycling metal commodities in the United States. U.S. Department of the Interior, U.S. Geological Survey, Washington, DC

22. Weast RC (ed) (1976) Handbook of chemistry and physics, 57th edn. CRC Press, Cleveland

23. JCPDS (2010) Joint committee of powder diffraction standards. In: JCPDS-ICCD 2010, Philadelphia

24. Gordon RB, Graedel TE, Bertram M, Fuse K, Lifset R, Rechberger H, Spatari S (2003) The characterization of technological zinc cycles. Resour Conserv Recycl 39(2):107-135

25. Irtyugo LA, Belousova NV, Denisov VM, Denisova LT, Kirik SD, Chumilina LG (2012) High-temperature heat capacity of bismuth oxide and bismuth-zinc double oxide with the sillenite structure. J Sib Fed Univ 2:125-130

26. Svensson C (1975) Refinement of the crystal structure of cubic antimony trioxide, $\mathrm{Sb}_{2} \mathrm{O}_{3}$. Acta Crystallogr B 31(8):2016-2018

27. Svensson C (1974) The crystal structure of orthorhombic antimony trioxide, $\mathrm{Sb}_{2} \mathrm{O}_{3}$. Acta Crystallogr B 30(2):458-461
28. Golunski SE, Jackson D (1989) Antimony oxides: a guide to phase changes during catalyst preparation. Appl Catal 48(1):123-135

29. Norman NC (1998) Chemistry of arsenic, antimony and bismuth. Blackie Academic \& Professional, London

30. Cody CA, DiCarlo L, Darlington RK (1979) Vibrational and thermal study of antimony oxides. Inorg Chem 18(6):1572-1576

31. Golunski SE, Nevell TG, Pope MI (1981) Thermal stability and phase transitions of the oxides of antimony. Thermochim Acta 51(2-3): 153-168

32. Orman RG, Holland D (2007) Thermal phase transitions in antimony (III) oxides. J Solid State Chem 180(9):2587-2596

33. Paoletti F, Seifert H, Vehlow J, Sirini P (2000) Oxyanions forming elements in waste combustion-partitioning of antimony. Waste Manag Res 18(2):141-150

34. Rosenqvist T (1974) Reduction of metal oxides. In: Clark BJ (ed) Principles of extractive metallurgy. McGraw-Hill, New York, pp 264-298

35. Rosenqvist T (1974) Volatile metals. In: Clark BJ (ed) Principles of extractive metallurgy. McGraw-Hill, New York, pp 299-321

36. Guger CE, Manning FS (1971) Kinetics of zinc oxide reduction with carbon monoxide. Metall Mater Trans B 2(11):3083-3090

37. Hong L, Sohn HY, Sano M (2003) Kinetics of carbothermic reduction of magnesia and zinc oxide by thermogravimetric analysis technique. Scand J Metall 32(3):171-176

38. Ebin B, Petranikova M, Steenari B-M, Ekberg C (2016) Production of zinc and manganese oxide particles by pyrolysis of alkaline and Zn-C battery waste. Waste Manag 51:157-167

39. Wong $\mathbf{J}$ (1975) Microstructure and phase transformation in a highly non-Ohmic metal oxide varistor ceramic. J Appl Phys 46(4):1653-1659

40. Filipek E, Dąbrowska G (2008) Unknown thermal properties of $\mathrm{ZnSb}_{2} \mathrm{O}_{6}$ and $\mathrm{Zn}_{7 \mathrm{Sb}_{2}} \mathrm{O}_{12}$ compounds. J Therm Anal Calorim 94(1):195-201 